\title{
History Of African Accounting Thoughts And Development: Evidences From Igbo Land
}

\author{
Luke N. Onuoha \\ Dept of Accounting \\ Babcock University, Ilishan Remo \\ Patrick E. Enyi \\ School of Management Sciences \\ Babcock University, Ilishan Remo
}

\begin{abstract}
The aim of this paper was to present the history of accounting thought in Africa with particular focus on Igbo land. The study is carried out via desk research. Secondary sources from journals, textbooks, internet sources and oral accounts have been adopted. The study reveals that Igbo people had a rich history of accounting thought which has remained partially documented. In some ways, accounting development experience of the Igbos was similar to the pre-history period experience of Mesopotamia, Egypt and other early civilizations as there were unique methods in the use of notches on sticks, vertical and horizontal marks on the wall, use of counters made of pebbles, grains and palm kernel stored in calabashes and wooden boxes as measurements of wealth. The 1494 double entry system published by Luca Pacioli, an Italian monk and mathematician, which brought sweeping changes in the method of recording business transactions across Europe and America, similarly affected the development of accounting in Nigeria. Also the formation of accounting bodies in Europe and America between 1854 and 1897 influenced similar developments in Nigeria which culminated in 1960 to the formation of the Association of Accountants in Nigeria and subsequently the charter of the Institute of Chartered Accountants of Nigeria (ICAN) by the Parliament in 1965. The formation of the International Accounting Standards Board (IASB) in 1979 added the dimension of internationality and comparability to the reporting quality in Nigeria. This paper will be of critical significance to accounting history researchers and students.
\end{abstract}

Key words: History of African accounting; accounting development; accounting thought.

\section{INTRODUCTION}

Accounting thought transverses three major periods in history, namely: pre-historic period, ancient times and recent developments. Several studies have attempted to relate the thinking of the three periods and there seems to be a convergence at the definition of purpose of accounting irrespective of the period in history as of ensuring efficiency, accuracy and timely financial reporting for effective decision making (Nwanyanwu, 2006). The development of accounting thought as related to the African hemisphere is the central focus of this paper which is structured into five sections, namely: introduction, methodology, theoretical clarification, evolution of accounting and later developments. Others are discussion and conclusion.

Accounting researchers appear to have consensus on the origin of accountancy. Different literature present early development of accounting to the pre-historic periods dating back to the ancient Mesopotamia which were not largely separable from developments in writing, counting, money and auditing systems linked to the Egyptians and Babylonians (Robson,1992; Oldroyd, 2008). There have emerged other reviews which showed different forms of 
accounting activities in the various parts of the world like India and Africa. However, in the dark ages, little knowledge was available that could offer detailed description of how records were kept of business and financial transactions. Observations of early researchers informed that the early practices of accounting were blurred by ignorance, use of vague parameters and deficient communication (George Jr., 1972).

Throughout times, governments, ecclesiastical organizations and businesses have sought to record their transactions and have detailed information about their financial dealings. In all the phases of times, even as is relevant to today's business environments, accurate and timely report of financial activities remains an important requirement for proper accountability and decision making. While users of financial reports may have increased by today's standards, it is obvious that financial records were not of more significance today than they were in the ancient times.

Governments in the pre-historic times needed to inform the citizens of the stewardship of their common resources entrusted with the king (Oldroyd, 1995). In 1370, the Merchants of Venice government legislated that trade activities be kept in Journals and Ledgers. This account preceded the later more widely practiced double entry system introduced by the catholic monk, Luca Pacioli in 1494 (Lauwers and Wilkens, 1994). In churches account was kept of tithes (Robson, 1992), businesses made records of inventory, debtors and expenses on tablets of stones (Oldroyd and Dobie, 2008) and farmers kept account of their gains after the cropping season (Friedlob and Plewa, 1996).

It is of important consideration to determine where Africa and Nigeria, in particular, were in all the course of historical developments of accounting thought. While the name of Egypt as an African country was in the forefront of civilization in writing and auditing systems, little was formally documented of the ancient history developments in Nigeria. Very limited literature and oral accounts exist about the early developments of accountancy in the different parts of Nigeria. This study attempted to trace some of the documented accounts and above all provide more insights on the oral literature available. This study provided opportunity to fill some of the identified gaps in this regard.

\section{METHODOLOGY}

This study adopted the expository approach using existing literature and other oral accounts. The secondary sources of data used for the study were obtained online through the internet and from review of articles by other researchers published in the available journals. The work is presented in a progressive order from introduction to accounting evolution, later developments, discussion and conclusion.

\section{THEORETICAL CLARIFICATION}

The purpose and practice of accounting in ancient Igbo culture had a strong leaning to what is known today as the Accountability and Agency Theories. The accountability theory stems from the ethical leaning that a person who had the trust of others' resources should account for the use of the resources. Lloyd, Oatham and Hammer (2007:9) affirm: "Accountability is not a theoretical pursuit; it's about holding power to account and enabling people to input into decisions affecting them. Organizations with high level of accountability founded on transparency, participation, evaluation, and complaint \& response attract confidence of stakeholders." Accordingly accounting in ancient times as is the case today was intended to ensure proper stewardship reporting to those who were connected with the resources such as tax payers, co-operative or family members. A clan head that collected taxes on behalf of the 
king had a duty to keep record of the collections and the expenses made out of the pool. The records were either in forms of marks on wall or counters in a calabash. This reconciles somewhat with the charge and discharge form of accounting of the early Roman Empire. Record keeping is the thrust of accountability and this was very squarely at the centre of ancient accounting in Igbo land.

The second relevant theory in ancient Igbo business transactional practices was the agency theory of modern day business engagements. Jensen and Meckling (1976) describe agency theory as attempt to explain relationship between employer (principal) and employee (agent) where one party ( the principal) delegates work to another (the agent). In the olden days, some wealthy Igbos engaged labourers to work in their farms for wages. Some of those were in the form of one person being given baskets of yams to cultivate, and tend until harvest. In such arrangements, the labourer had a duty to account to the yams owner in same fashion that could be likened to the agency principle of modern day business engagements. This was also the case in animal leasing transactions in which one person was given a female cow, or goat or chicken, for instance, to tend and to report later of any multiplications of the young which were then shared between the owner of the animal (the principal) and the one tending the animal (agent). To make a success of the relationship, the lessee (or agent) took appropriate care of the item trusted to him and had a duty of reporting of any increases to the lessor (owner) from time to time.

The two theories explained in the foregoing paragraphs strongly underlie the ancient Igbo accounting phenomenon.

\section{EVOLUTION OF ACCOUNTING AND LATER DEVELOPMENTS}

This section looked at the evolution of accounting thought and the later developments. The section is subdivided into four parts, namely: Early Accounting thought in the Holy Bible, Accounting in pre-history period, the double entry bookkeeping, and Later Developments.

\section{Early Accounting Thought in the Holy Bible}

It would seem correct to assert that most available Accounting evolution literature have repeatedly failed to report the true origin of Accounting by their glaring non-inclusion of the Holy Bible narratives of Genesis 2 and 3 where God gave Adam the responsibility of naming all the livestock, and where he later was queried over his indulgence at the consumption of the forbidden fruit. The separate texts state:

"Out of the ground the Lord God formed every beast of the field and every bird of the air, and brought them to Adam to see what he would call them. And whatever Adam called each living creature that was its name. So Adam gave names to all cattle, to the birds of the air, and to every beast of the field..." (Genesis 2: 19, 20a).

"Then the Lord God called to Adam and said to him, 'Where are you?' So he said, 'I heard your voice in the garden, and I was afraid because I was naked; and I hid myself.' And He said, 'Who told you that you were naked? Have you eaten from the tree of which I commanded you that you should not eat?'” (Genesis 3:9-11).

These Bible references inform that on the sixth day of creation Adam performed inventory tagging' by giving names to "every beast of the field and every bird of the air" (Genesis 2: 19, 20a). This was the first ever accounting function performed in history. The second citation shows that in yet a later encounter with God, after Adam and his wife had eaten of the 
forbidden fruit, 'Auditing', a branch of accounting, also began right at creation (Genesis 3: 911). These evidences suggest that Accounting and Auditing had, indeed, began several years before the often published reports by several earlier accounting researchers.

\section{Accounting in the Pre-history Period}

Other available literature traces accounting to pre-history periods 9,000 to 10,000 B.C. (Nwanyanwu, 2006). The common notion was that since this era preceded the invention of writing materials, accounting records were kept "by making notches on sticks" (Nwanyanwu, 2006:144). The accounting activities at this time were associated with ancient Egypt, Mesopotamia, and Sumerians (Robson, 1992). Kings and priests who headed small village settlements required taxes from the people and were required to give account of the revenue received. Because writing materials were not yet existent, accounts were rendered by making marks on sticks to indicate amount collected and the amount of the surplus after expenses (George Jr., 1972).

The foregoing narrative indicates that the primitive form of accounting was nebulous (Nwanyanwu, 2006). While later the Sumerians introduced clay tablets for writing, making marks on walls and notches on stick for financial accounting of taxes, revenues collected, loans given and flocks of sheep, a practice that became popular in most ancient civilizations, Nigerian methods differed somewhat. Ischemia (1992) asserts that in Nigeria, Agriculture influenced all of life including the record keeping methods. He points out that materials like calabashes, bamboos, seeds and grains, tally sticks and ropes were used for accounting. He further documents that house walls, wood and animal bones were used for record keeping at different places. Some of the vertical marks made on house walls were with red palm oil and charcoal accounting for quantity of inventories of sheep, goats and yam. Others are revenues collected, debts owed, and profits earned. However, because of the vague nature of the details, it is only the bookkeeper who knew what the marks represented (Asechemie, 1992).

\section{Ancient Accounting Thoughts from Igbo Land}

Different forms of ancient accounting existed in Igbo Land. Some of these evidences are adaptations from age long oral accounts from Igbo elders.

\section{Marks on the Wall}

Some of the ancient accounting was in the form marks on the wall made with either red oil or white chalk or even charcoal. Nwanyanwu (2006) cites examples of wall strokes and what they represented in ancient days in Nigeria. While five vertical strokes (see Fig. 1) represent debt of five pounds owed to a creditor, six vertical strokes and a crossing laid horizontally (see Fig. 2) represent revenue of seven pounds (p.145), thus:

Fig. 1: Record of Five Pounds owed

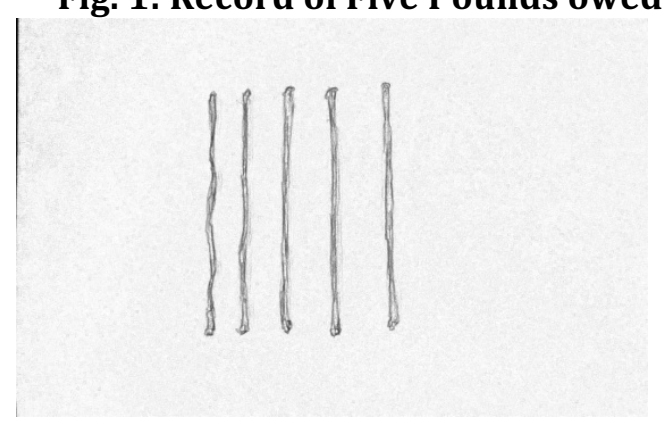

A debt of five pounds

Source: Nwanyanwu (2006:146) 
Fig. 2: Record of Revenue Collected

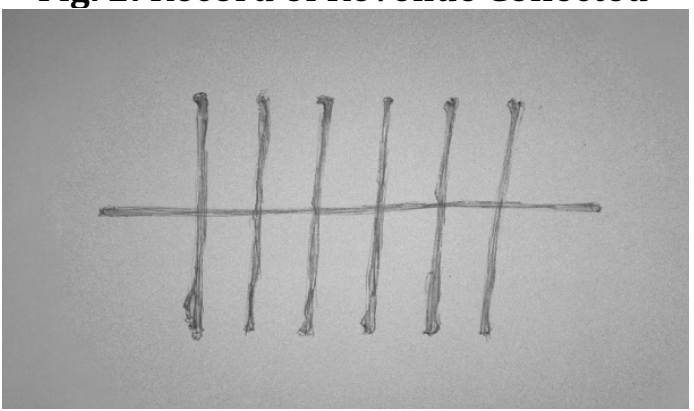

Revenue of seven pounds

Source: Nwanyanwu (2006:146)

Early accounting thought was also applicable in private debt management. For instance, In Things Fall Apart, Achebe (1958) stated what could be described as debt management in the ancient times by a character in the book, Anoka, who used lines on the wall to explain to his creditors the priority order in which he was going to settle the debts he owed. According to the author, Anoka made horizontal lines on the wall with the first line being longer than the second; the second, longer than the third; the third, longer than the fourth, etc. When a creditor approached Anoka, he would show him that his position in the order was, say third, and that there were yet two other longer lines above the third which would first be settled. Examples of the lines on the wall described in the above scenario were as follows:

Fig. 4: List of Creditors by Size of Amount Owed

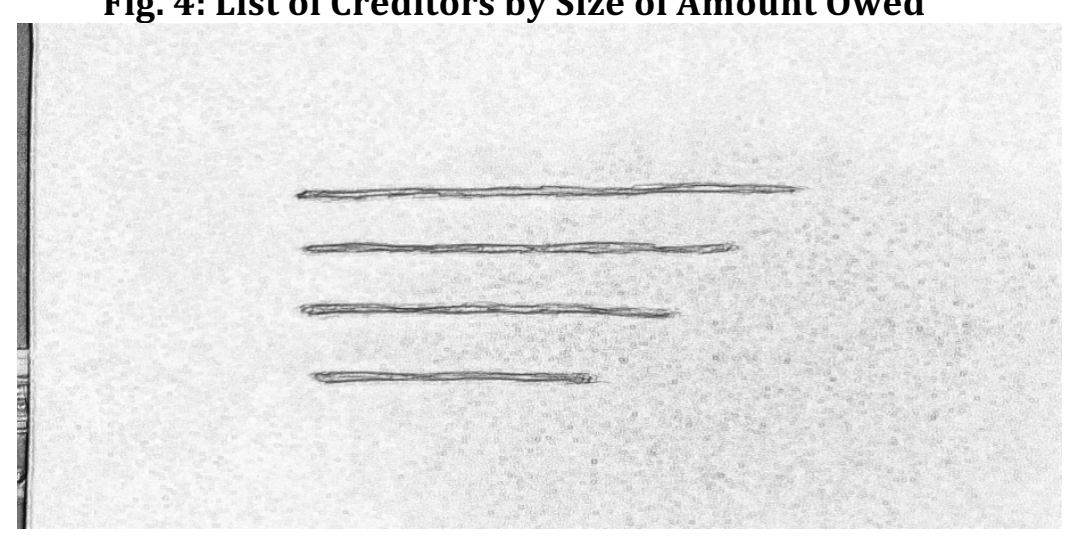

List of four creditors in the order of Size of amount owed

\section{Source: Adapted from Things Fall Apart}

The narrative goes that pointing at the lines he made on the wall, Anoka would say to the creditor who had come to collect his overdue money:

"The sun will shine on those who stand before it shines on those who kneel under them." (Achebe, 1958:11)

The meaning of the statement above was that Anoka, the debtor, would have to pay the person he owed the biggest amount represented by the first and longest line; then the second which was the longer line; then the third, etc., in that order. The implication of the debtor's message was that the third creditor represented by the shortest third line on the wall should wait for the first and the second to be paid before asking for his own money. Thus, Anoka, cleverly kept his creditors at bay with his ingenious 'debt management' thought! 


\section{Use of Counters}

Besides the strokes and marks on walls, counters (Fig. 3) were equally used to account for financial activities involving debtors, creditors, and stocks of goods (Nwaanyanwu, 2006; Asechemie, 1992). The counters were pebbles, stones, grains, seed and palm kernels stored in a calabash. Asechemie (1992), reports that while grains were preferred among the northerners, palm kernels were common among the southerners. The container with counters below is a typical example:

Fig. 3: Calabash container of Counters

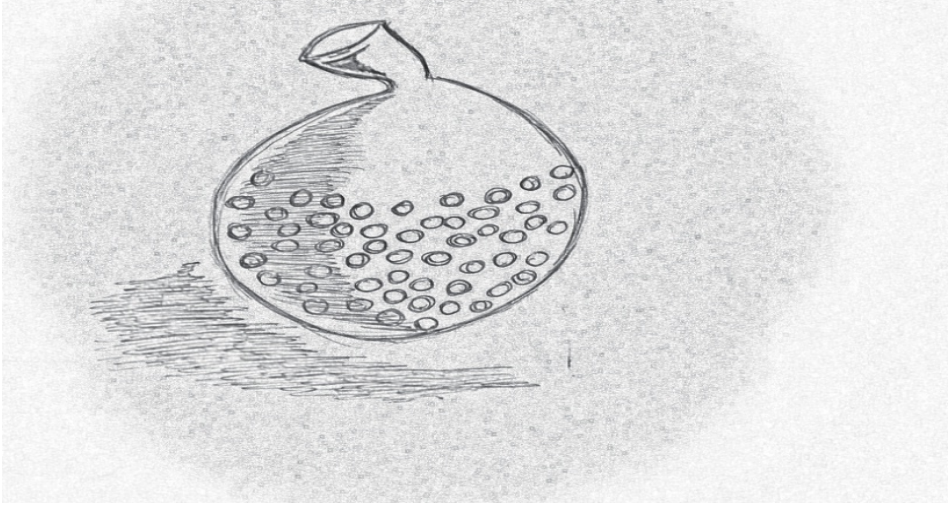

A counter container

Source: Asechemie (1992: 33)

\section{Accounting for Debt Repayment}

Enyi (2017) discussed a form of accounting in ancient Igbo land where the creditor used two bows and counters to account for debt owed and amount paid at any given time. The process involved holding in Bow 1 a number of counters equivalent to the total sum owed and removing one from Bow 1 to bow 2 each time a given installment is paid by the debtor. To ascertain what has been paid or how much was still owed at a given time, the counters in each bow were counted (see figure 4).

Fig. 4: Debt Repayment Accounting in Ancient Igbo Land

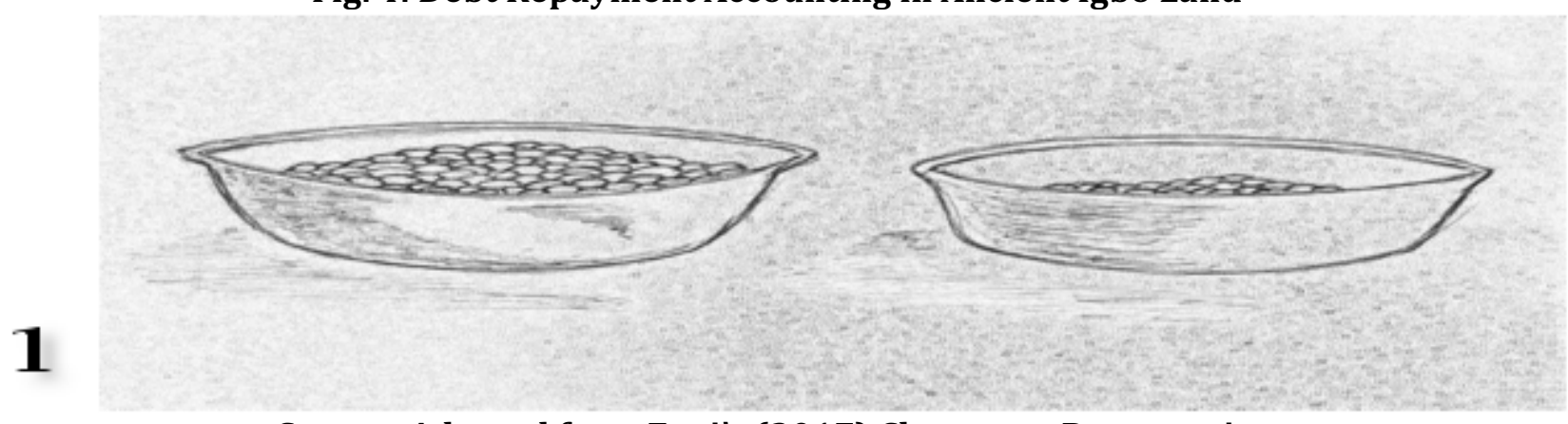

Source: Adapted from Enyi's (2017) Classroom Presentation

\section{Measurement of Wealth in ancient Igbo}

According to oral stories transmitted over several centuries Igbos attached so much importance to making and managing wealth. Different resources have been reported as standards of measurement of wealth employed by the ancient Igbos. One of such is the number of barns of yams cultivated by a man. A yam barn is a collection of connected bamboo stands on which are tied for preservation rows and columns of yam tubers. During the ancient 
days, a man's net-worth was determined by the number of row-columns of yam barns he stores away prior to the iri ji (yam eating) festival each year. Men took many wives and produced more children to grow helping hands in their yam farms. It was indeed a great pride for a man to be associated with ownership of ten; twenty or thirty row-columns of yams in his barn (see Fig. 5).

Fig. 5: Yam barns: Measurement of wealth in ancient Igbo Land

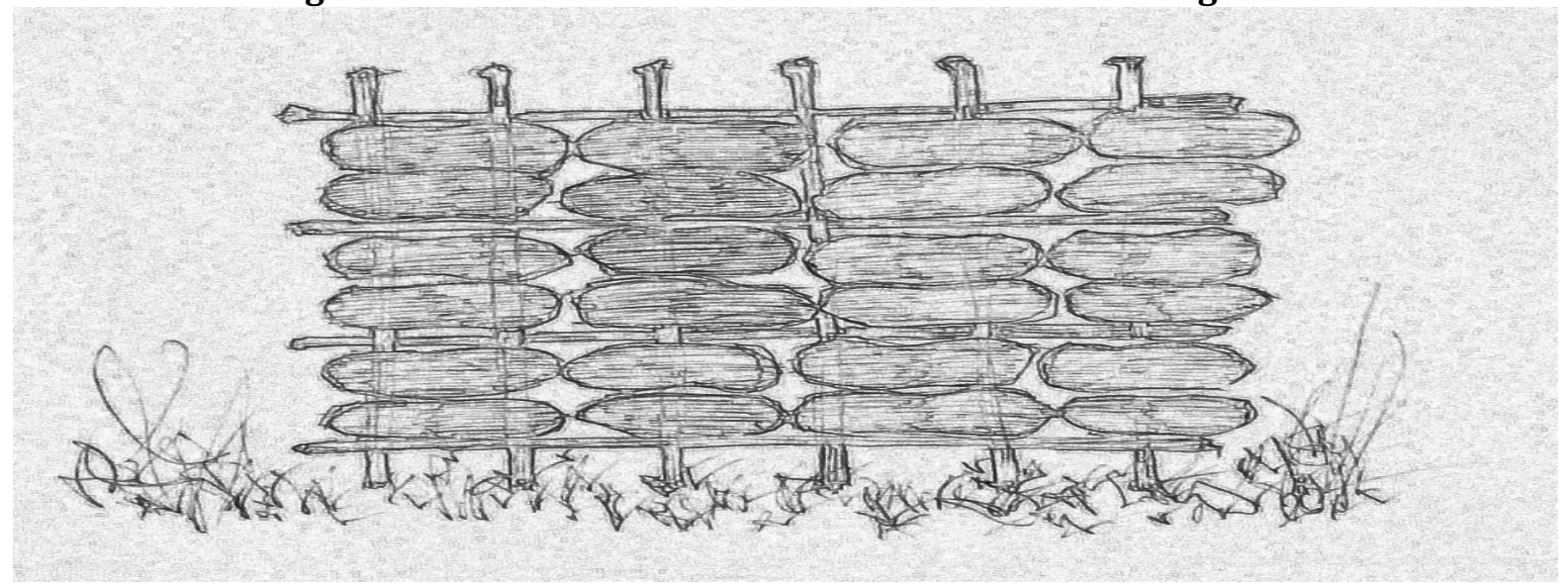

Source: Researchers Adaptation from oral tales

Another form of wealth measurement was associated with how many bags of counters that a man had in his depository. A depository (see Fig. 6) was made up of calabashes/bags containing equal number of counters stored away in a

Fig. 6: Depository of Counters in bags of 10 pounds each

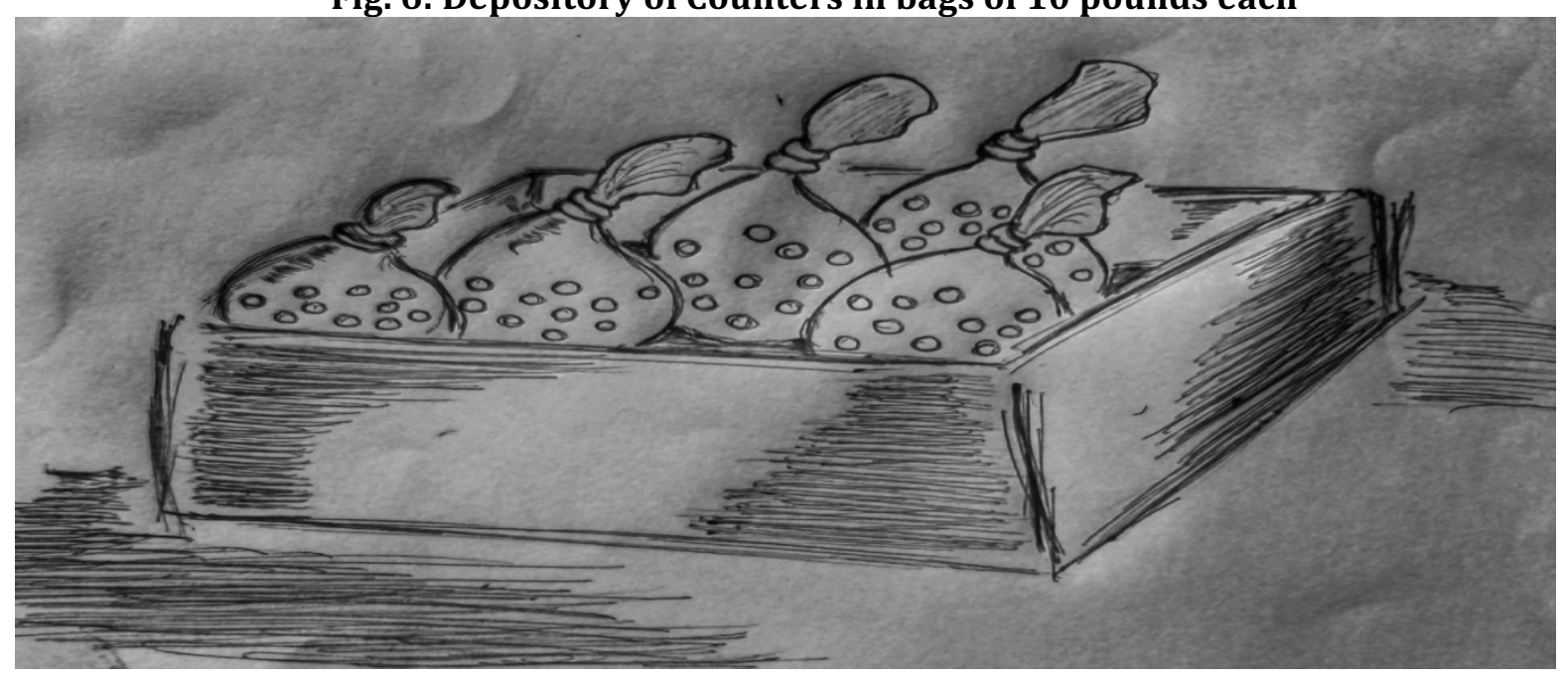

Source: Researcher's adaptation from oral tales

wooden box normally kept in the inner chambers of the owner's house. The containers/bags had in them between seven pounds and ten pounds and one could determine how much wealthy a man was by simply looking at the number of calabashes/bags of counters he had on his depository. This practice continued for a long time even up to when money (cowries/coins) came in vogue. It was easy to talk about a man's wealth by referring to the number of cowries/coin bags he possessed and men of wealth took so much pride in growing the number of cowries/coin bags. 


\section{Animal lease}

The tale of animal lease was a form of wealth creation practice according to Igbo ancient financial practices. The process involved a person giving over animals (fouls, goats and cows) to a less wealthy person for care and keeping. The mode permitted the second person to have custody and to tend the deposited animals for a long period of time.

Fig. 7: Cow Lease/Joint Venture in Ancient Igbo Culture

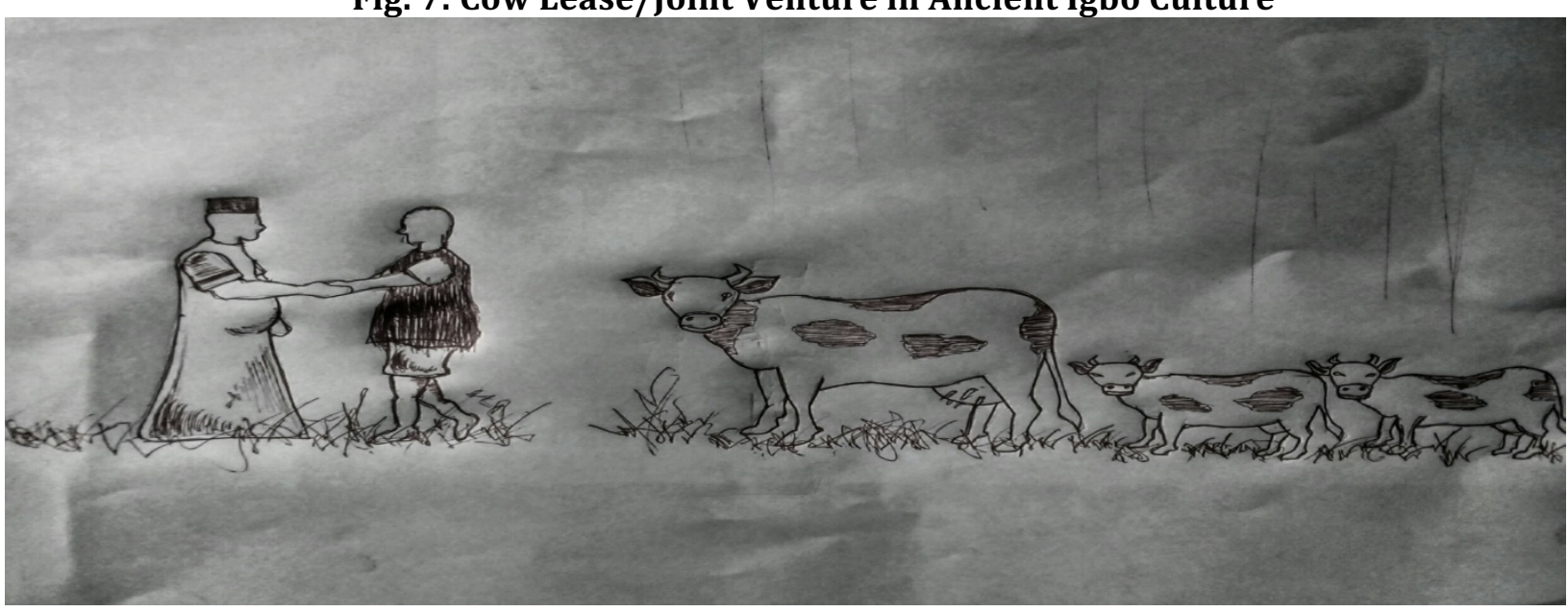

Source: Researcher's Adaptation from Oral Tales

It was his responsibility to bring the offspring for sharing from time to time. Where the animal, for instance, gave birth to only one young, the owner took the first while the lessee was entitled to the offspring the next time around. For other animals like goat which could produce up to three young at the same time, the lessee was entitled to one out of the three. In some instances, the lesser and the lease agreed to share according to the colors of the young, for example, all white young to the owner and all black or spotted ones to the lessee (a culture borrowed from the Israelites of old). Figure 7 shows a rich man and his lessee with the leased animal and its young.

\section{Difficulties associated with ancient accounting thoughts}

Marks on the wall and other forms of ancient accounting representations were faced the problem of different interpretations. At best a researcher has called it nebulous because marks on the wall, counters in a calabash or notches on sticks had different meanings for different observers. At best it is only the one who put the mark on the wall that can more readily explain the meaning. This means that the ancient accounting lacked objectivity and comparability.

Unegbu (2014:12) asserts that accounting development has been affected by language and culture. In the ancient times, Igbos used counters of agricultural products and animals as measures of wealth. These objects had diverse imports for the various cultures which lacked universality. Stoner, et al (2002) and Akanni (1988) have variously identified cultural diversity and language barriers as having played instrumental roles in constraining the development of accounting.

The observation of George Jr. (1972) observation that the early practices of accounting were blurred by ignorance, use of vague parameters and deficient communication has important relevance to the ancient Igbo accounting experience. Consider the reporting of debts or revenues by vertical or horizontal marks on the wall. How, for instance, does one know that a vertical or horizontal line on the wall represents debts or revenues except if one is told by the 
person who put the mark there in the first place? How much was a man with ten barns of yams worth in comparison with another man from the North who had 100 cows, for instance? It may be concluded in aggregate that ancient accounting involved using incongruent and incomparable objects. By these constraints, it may be appropriate to reinstate that the development of accounting thought by the ancient parameters was a very difficult engagement.

Among other things Unegbu (2014) comments that researchers have found illiteracy among the difficulties associated with ancient accounting development.

This observation arises from the obvious knowledge that the ancient rich were not educated. The marks on the wall or the counters in a calabash were crude representations of the business activities. There were not informed categorizations and definition of the data, and their incomparability with other reports across tribes, constrained the appreciation of the value of the reports.

\section{The Double Entry Bookkeeping}

In 1494, Luca Pacioli, an Italian mathematician published the double entry system of bookkeeping which was later adopted throughout the whole world (Nwanyanwu, 2006; Lauwers, et al., 1994). Pacioli's novel publication was a response to the growing need for proper accountability for the largely expanding trade and commerce in Italy and other European lands in the $15^{\text {th }}$ century. The translation of Pacioli's work into five other languages within its first century of publication gave the book far wider acceptance within Europe. This paved way for tremendous growth in accounting education in Europe, and later, America and around the whole world. The publication formed the stop gap between ancient accounting method and contemporary accounting paradigm (Nwanyanwu, 2006).

\section{Later Developments - formation of Professional Accountancy Bodies}

Luca Pacioli's introduction of the double entry system became a great light to accounting education in several countries (Sangster, Stoner and McCarthy, 2007). During the same period, the expansion of commerce and the importance of taxation created a strong need for record keeping of revenues and payments (Oldroyd, 1995). Europe and America caught the fire first and commercially trained accountants began to exchange views in accounting through articles and journal publications (Nwanyanwu, 2006). In America, Previts and Merino (1979) argued that to tackle corruption and inefficiency, politicians should be held responsible for their actions. These positions popularized accountants and brought more people to appreciate the role accountants.

Ifede (2011) reports of the formation of the Institute of Chartered Accountants of Scotland in 1854, which opened the way for increased professional engagements by accountants across Europe and America. Perks (1993) notes the formation of the Institute of Chartered Accountants of England and Wales (ICAEW) in 1880. He further remarks that ICAEW was the outcome of the merging of some local professional bodies in England. This was quickly followed by the 1887 formation of the American Association of Public Accountants (AAPA) which later changed its name to the American Institute of Certified Public Accountants (AICPA) in 1897. The earlier accountants in Nigeria had their training and influence from the England and Wales body (Ifede, 2011). In 1960, the Association of Accountants in Nigeria was organized and helped in the formation and charter of the Institute of Chartered Accountants of Nigeria (ICAN) by Act of Parliament in 1965. Since its formation, ICAN has pursued vigorously its stallion objectives of: 
- Determination of the standards of knowledge and skills to be attained by persons seeking to become members of the accountancy profession and raising the standards from time to time as circumstances my require;

- Securing in accordance with the provision of the Act the establishment and maintenance of Registers of Fellows, Associates and Registered Accountants entitled to practice as Accountants and Auditors and the publication from time to time of lists of those persons and,

- Performing through the Council of the Institute all the functions conferred on it by the Act, Section 1(a)(b) and (c).

In order to provide sound professional training to the middle level manpower, the Institute established the Accounting Technician's Scheme (ATS) in September 1989. Also in 2007, the Association of Accountancy Bodies in West Africa (AABWA) of which Nigeria is a leading member, came together to regulate examinations of the Accounting Technician's Scheme for all the countries of West Africa (ATSWA). The involvement of members of the institute in practice or not in practice is viewed with high esteem for their manifest integrity, objectivity, confidentiality and independence in the discharge of their services in areas of auditing, financial management, taxation and advisory services, consultancy and management (Ifede, 2011).

\section{DISCUSSION}

The development of accounting in Africa, like in the rest of the world, began with very crude methods. The use of lines on the wall and notches on stick were typical of the Igbo approach. Counters were commonly used involving agricultural products such as grains, palm kernel and other items like pebbles and cowries. Recording was unsystematic and nebulous. Cultural differences and language barriers did not help matters.

The publication of the book on double entry in 1494 by Luca Pacioli, however, paved way for improved recording of business and financial activities all over the world. Nigeria (Igbo land accordingly) was equally a beneficiary of the novel system as more knowledge grew in the subsequent centuries following the formation of the Institute of Chartered Accountants of Scotland in 1854; the Institute of Chartered Accountants of England and Wales in 1860; the American Institute of Certified Public Accountants in 1897 and the Institute of Chartered Accountants of Nigeria (ICAN) in 1965. Evidently, early Nigerian accountants were trained by the Scotland and England \& Wales bodies. This presupposes that the later development of Accounting in Igbo land of Nigeria was tremendously influenced by the European practices. The activities of ICAN and the Nigerian Accounting Standards Board (NASB) have raised the standard of training and practice of accountants in Nigeria to a much greater height.

The foregoing accounts were not without serious constraints. Unegbu (2012) predicated the divergences on culture, language, government and regulatory differences. Nwoko (1988) corroborated that incessant changes in government policies and the thought of indigenous ideology among accounting professionals from the different countries of the world added to the difficulties in the advancement of accounting thought. Robert, Joesl, and James (1990) affirmed that, indeed, there was no watertight system anywhere and accounting was never an exception.

Although globalization and adoption of International Financial Reporting Standards (IFRS) have tremendously narrowed the impact of these two in the practice of accounting today, early accounting thought suffered grossly. Consider the case in Nigeria where grains were preferred 
counters in the North and palm kernel in the south. There were no informed unified basis for reporting financial information and this was a serious barrier to interpretation and comparability of the accounting data.

Benjamin (1990) pointed out that the early accountants lacked broad knowledge of accounting, and the practitioners were not research oriented. Up to the late 1900s, many people in banking, insurance and public sector organizations assumed the title of accountants even when they had no sound background of accounting. The constraint this brought against research capability and development of accounting was enormous. Anao (1996) affirmed that the disagreement between academicians and practitioners did not help matters. Until recently, one could not speak of unified objectives between the academicians and the practitioners. The continuous feud between academicians and accounting practitioners was a huge hindrance to the development of accounting.

Gautier and Underdown (2001) argued that diversity of government policies hindered early accounting development. Their argument was that independence immunity of sovereign countries affected choices of nature, scope and application of accounting systems unique to the various socio-economic and political environments. From a different point of view, Mootze (1970) echoed the difficulties posed by unstable monetary units and fragility of the different national economies.

Paul (1985) reiterated that environmental factors, cultural background, religion and political factors influenced treatment and interpretation of business transactions from one country to the other. Millichamp (1990) saw constraint to accounting development bothering on money as a unit of measure. From country to country, and even within the same nation, money unit never remains stable over a long period of time. In all the circumstances, comparability of the financial statements was not possible internationally.

Illiteracy has had a serious impact in the early development of accounting. Until Pacioli's publication of the double entry system in 1494, the world was in a period of 'dark ages'. Information was not available in a documented form about most business activities. In Africa and Nigeria, in particular, people lacked knowledge of how to read and write. Ignorance and lack of statistical data was the order of the day and the development of accounting was very highly constrained in the early days (Unegbu, 2014). The formation of accounting bodies and the increased knowledge in the $21^{\text {st }}$ century made possible through different journals have eased the initial difficulties associated with accounting development (Mootze, 1983; Anao, 1996). There are far more knowledgeable accountants today than four centuries ago.

The formation of the International Accounting Standards Board (IASB) through the issuance of the International Financial Reporting Standards (IFRS) has tremendously advanced accounting development and comparability of the financial statements throughout the globe. Focusing on efficiency, accuracy and integrity, these harmonized standards have enhanced transparency, quality and comparability of financial statements.

\section{CONCLUSION}

Accounting thought and development in Igbo land (and Nigeria as a whole) began in a crude and rudimentary fashion. Marks on walls, notches on sticks, counters in calabashes, barns of yams were used as business and financial reporting parameters. The crude methods engaged in the Igbo land appeared similar to the practices in some other parts of Nigeria and the rest of Africa. Africa was influenced by the same origin as for the rest of the world. 
In general, it would appear that from creation when God gave Adam the role of inventory officer (by giving him responsibility to ascribe names to all the animals in the Garden of Eden), early accounting thought was rudimentary and nebulous. Recording of transactions, revenues, debtors and taxes were by making marks on the wall and the use of counters. But Luca Pacioli's 1494 book of double entry changed the way of record-keeping and introduced what is known today as modern accounting. As more efficient and accurate financial reporting spread in Europe and America, Africa (Nigeria, most importantly) were not left out. The formation of accounting bodies tremendously gave way for better accounting training and practice. Nigeria borrowed leaf from European practices. Currently, the International Accounting Standard Board (IASB), through the issuance of IFRS has played a huge role in ushering in international comparability of financial statements in many countries of the world. Despite all the initial challenges associated with adoption of IFRS by different countries, Africa and Nigeria, in particular, are beneficiaries of series of evolutions of accounting thoughts from pre-history period to the present day.

\section{References}

Achebe, C. (1958). Things Fall Apart. Nigeria: William-Heinemann Ltd.

Anao, A.R. (1996). An introduction to financial accounting. Lagos: Longman Nigeria Ltd

Asechemie, D.P.S. (1992). A history of accounting in Nigeria. Port Harcourt, Nigeria: CSS Press.

Benjamin, O. (1990). Studies in Accountancy, text and readings. Enugu: New Age Publishers.

Enyi, P.E. (2017). Being oral presentation in 2017 class of History of Accounting Thought: the Igbo thoughts.

Friedlob, G.T. \& Plewa, F.J.(1996). Understanding balance sheets. NYC: John Wiley \& Sons.

George, Jr. (1972). The history of management thought. New Jersey, USA: Prentice-Hall Inc.

Glautier, M.W.E. \& Underdown, B. (2001). Accounting theory and practice ( $7^{\text {th }}$ Ed). New York: Prentice Hall Financial Times.

Holy Bible (1992). Thomas Nelson, Inc. Pages 3,4 Genesis 2: 19, 20a; 3:9-11

Ifede, A.I.(2011). Fundamentals and Practice of Financial Accounting. Ibadan: Gondolier I. Ventures.

Jensen, M.C. \& Meckling, W.H. (1976). Theory of the firm: managerial behavior, agency costs and capital structure. Journal of Financial Economics, 3, 305-360.

Lauwers, L. \& Willekens, M. (1994). Five hundred years of bookkeeping: a portrait of Luca Pacioli. Tijdschrift voor Economie en Management, katholieke Universiteit Leuven. XXXX1X (3), 302.

Lloyd, R., Oatham, J. \& Hammer, M. (2007). 2007 Global accounting report. London: One World Trust.

Milichamp, A.N. (1990). Auditing: an introductional manual (5 $5^{\text {th }}$ Ed). London: DP Publication Ltd.

Mootze, M. (1970). Three contributions to the development of accounting principles prior to 1930. Journal of Accounting Research, AAD. 8(1), 145-155.

Nwanyanwu, L.A. (2006). History of accounting: Some perspectives on the Nigerian situation. Knowledge Review, 12 (2), 144-150

Oldroyd, D. (1995). The role of accounting in public expenditure and monetary policy in the first century AD Roman Empire. Accounting Historians Journal. 22 (2), 124.

Oldroyd, D. and Dobie, A. (2008). Themes in the history of bookkeeping, London: the Routledge companion to accounting history, 96.

Paul, G. (1985). Book-keeping and Accounts (19th Ed). London: Butterworth \& Co Ltd.

Perks, R.W. (1993). Accounting and Society. London: Chapman \& Hall

Previts, G.J. and Merino, B.D (1979). A history of accounting in America. USA: John Wiley \& Sons Inc.

Robert, G.M.; Joesl, E.R. \& James, R.C. (1990). Information systems for modern management (3rd ed). New Delhi:

Prentice Hall of India Ltd. 
Robson, K. (1992). Accounting numbers as inscription: Action at a distance and the development of accounting. Accounting, Organizations and Society. 17(7), 685-708

Sangster, A., Stoner, G., \& McCarthy, P. (2007). The Market for Luca Pacioli's summa arithmetica. Paper presented at Accounting, Business \& Financial History Conference, Cardif. September 2007, 1-2. Accessed from Cardiff.ac.uk. Stoner, J., Freeman, R., \& Gilbert, D.Jr (2002). Management, (6 $6^{\text {th }}$ Ed). India:Prentice Hall.

Unegbu, A.O.(2014). Theories of accounting: evolution \& developments, income determination and diversities in use. Research Journal of Finance and Accounting. 5(19), 1-15 